\title{
PROPOSALS FOR CHANGES OF TAX THRESHOLDS AND TAX-FREE AMOUNT AS ONE OF THE ELEMENTS OF THE REFORM OF TAXATION OF NATURAL PERSONS NOT CONDUCTING BUSINESS ACTIVITY
}

The discussion concerning the reform of the existing tax system has been taking place in Poland for many years. Particularly urgent discussions are held over changes, which are proposed by various groups, in natural persons income tax. The demand for a radical simplification of this tax through liquidation of all tax relieves and the introduction of one tax rate for all persons charged with this tax appear cyclically.

The aim of the propositions of the reforms is not only the desire to facilitate and simplify the tax system but also a very popular idea to reduce citizens' tax charges.

The belief that the only way of achieving the latter aim is the introduction of the linear tax, which is sometimes presented in the press, is untrue. The very reduction of the tax rates does not have to lead to the increase of the taxpayer's remuneration. In some cases such a reduction may even lower the remuneration. Such a result could be observed in the Czech Republic where the linear tax at the amount of $15 \%$ was introduced. ${ }^{1}$

Thus, in reality not only the very tax rate of the income tax has the influence on the fact how much money rests in a taxpayer's pocket. The taxpayer's net income is also influenced by the existing tax relieves, as well as the height of the tax thresholds and the tax-free amount.

\section{The existing legal status/situation}

The basic legal instrument regulating taxation of natural persons not conducting business activity is the Act of 26 July 1991 on natural persons income

1 E. Maliszewska, The linear tax with relieves would be beneficial for Poland, "Gazeta Prawna", No. 126, 2008, p. 12. 
tax. $^{2}$ Despite many amendments, the natural persons income tax still retains its progressive character. In consequence, with the increase of the taxation base, i.e. the rise in the subsequent income thresholds, the income rate is also increased (stage progression).

In accordance with the npita, the height of the income tax due is the product of the two amounts: the taxation base and a given tax rate. In 2008 three tax rates are binding 19,30 and $40 \%{ }^{3}$ The additional elements which modify the height of the tax due are the following: the tax-free amount, tax thresholds within the progressive taxation model, tax deductions, deductions from the income, social security fees, etc. $^{4}$

The tax thresholds which were established in 2008 for the rates 19, 30 and $40 \%$ are: less than 44.490 PLN, between 44.490 and 85.528 PLN, more than 85.528 PLN respectively. ${ }^{5}$

The construction of the natural persons income tax also includes the tax-free amount. In 2008 the tax-free income is 3.091 PLN (the amount reducing the tax 586,85 PLN) ${ }^{6}$

From the beginning of the existence of npita the determined amounts of the tax thresholds were included. In 1992 the tax thresholds were determined at the following levels: less than 64.800.000 PLN, between 64.800.000 and 129.600.000 PLN, more than 129.600.000 PLN (amounts before the denomination). These amounts were increased by 2008 to 44.490 PLN, $44.490-85.528$ PLN and 85.528 PLN respectively. In the years between 1992 and 2008 there were also periods when the tax thresholds were frozen. It happened in the following periods: 1992-1993 and 2001-2006. The freeze of the tax thresholds has been always related to the increase of the citizens' tax burden. In particular, in the period between 2001-2006 more and more citizens, after exceeding the height of the income stated in the act, had to pay tax according to the tax rates higher than the basic one. It was not related to the subsequent increase of the living costs and existing inflation. Thus, it evoked widespread critical opinions.

In 2007 the tax thresholds were increased to 43.405 PLN, between 43.405 PLN and 85.528 PLN and more than 85.528 PLN. ${ }^{7}$ Moreover, to the regulations of npita a new reduced tax scale, which will be binding from 2009 , was introduced. In

2 Natural Persons Income Tax Act of 26 July 1991 (i.e.: Journal of Laws of 2000, No. 14, item 176 with amendments, herein referred to as npita).

Ibidem, article 32 point 1.

A. Bartosiewicz, R. Kubacki, Natural Persons Income Tax Act. Commentary, Warsaw 2005, p. 1027.

Under the amendments introduced into npita from 16 November 2006 on a change of natural persons income tax act and some other acts (Journal of Laws No. 217, item 1588, herein referred to as an act on a change of npita)

7 A change introduced by provisions of the act mentioned in the footnote no. 6 . 
accordance with this scale, from 2009 two tax rates of $18 \%$ and $32 \%$ will be binding and three tax sections will be replaced by -two: less than 85.528 PLN and more than this amount. ${ }^{8}$

Similar to tax thresholds, npita has always included the amount reducing tax stating the income from which the income tax from natural persons was not charged. Since 1992, when the amount was 864.000 PLN (before the denomination), it increased to 586,85 PLN in 2008 (the tax-free income 3.091 PLN). In the periods 1992 and 2003-2006 the tax-free amount was not increased, which evoked criticism.

It is surprising that together with the planned introduction of two tax rates in 2009 the tax-free amount was not increased. For 2009 the amount reducing tax is 556,02, which relates to 3.089 PLN of the obtained income. In comparison to 2008, when the amounts were 586,85 PLN and 3.091 PLN respectively, there was no increase of the tax-free income. ${ }^{9}$

\section{Propositions of various groups and the chances of realization}

The obtained solutions do not seem to be final. Various groups still come forward with various propositions of changes, which in their opinion will improve the solutions established in the income tax from natural persons.

Representatives of the government, Ministry of Finance, employers, tax advisors and other groups take part in the discussion. However, until now no homogeneous position has been established concerning the direction of possible changes in the income tax from natural persons.

Professor Leszek Balcerowicz, who proposed the introduction of the linear tax in 1998, belongs to the supporters of the simplification of the income tax from natural persons and liquidation of the tax thresholds. ${ }^{10}$

The supporter of the linear tax and liquidation of the tax thresholds is also Jeremi Mordasiewicz, the economic expert of Polska Konfederacja Pracodawców Prywatnych Lewiatan (Polish Confederation of Private Employers Lewiatan). However, he believes that people obtaining income below the minimum of the existence should not be charged with tax whereas the tax-free amount for each child should be retained.

$8 \quad$ Ibidem, art. 1 point 28.

9 The tax-free amount established in accordance with the existing tax scale.

10 L. Balcerowicz, The linear tax - lost chance?, "Businessman.pl”, no. 7-8, 2008, p. 3. 
There are also some critical opinions, which state, among others, that the introduction of the linear tax today would be beneficial mostly for high-ranking public officials and employees of the companies owned by the State Treasury of the higher and middle level of management. These people do not create new posts therefore they do not contribute directly to the development of the economy. ${ }^{11}$

Particularly active in proposing new solutions are political parties, which in particular during the pre-election campaign indicate changes within the scope of taxation of natural persons not conducting business activity which they would like to introduce in the future.

The election slogan of the leaders of the nowadays largest governing party "Platforma Obywatelska" (PO - Civic Platform) ${ }^{12}$ was transformation of Poland into the "second Ireland." The way of achieving this was to introduce similar solutions in Poland, almost identical to those existing in Ireland. What are these "model rules" of taxation of natural persons, and is PO really aspiring to introduce them in Poland?

In Ireland personal income tax is paid according to two tax rates: $20 \%$ and $41 \%$ along with high tax thresholds. ${ }^{13}$ For 2008 the tax thresholds were increased once more and the height of the various tax relieves was increased. It is estimated that as a result of these changes almost 900 thousand people will not pay the tax at all. It practically means that almost one in every three employees in this country will not be charged with tax. Even those who will pay the tax according to the accepted solutions will save at least 140 euro per year, even without benefiting from additional relieves. While benefiting from relieves and being married, a citizen of Ireland may save even over 1000 euro per year.

The height of the tax-free income in 2008 is 17.600 euro. However, it might be greatly increased by benefiting, for example, from a residential relief, refund of parts of the treatment costs, trade union fees or being married to an unemployed person or a person on a small income. In 2008 single people pay $41 \%$ tax from the income exceeding 35.400 euro per year, single parents 39.400 euro per year, married couples with one income from the remuneration higher than 44.400 euro per year, married couples in which both spouses work 70.800 euro per year. Theoretically, $41 \%$ tax should be paid by over one million of the Irish, however, the majority of them manage to avoid it by tax deductions for pension funds or real estate investments. ${ }^{14}$

Then, is PO going to introduce solutions accepted in Ireland after winning the elections to the parliament? It turns out that despite the pre-election declarations,

11 What do we need the linear tax for?, "Businessman.pl", no. 7-8, 2008, p. 76-80.

12 Herein referred to as $\mathrm{PO}$

13 E. Matyszewska, Ireland possesses a clear tax system, "Gazeta Prawna" a supplement "Tygodnik podatkowy", no. 234, 2007, p. A13.

14 B. Świąder, Ireland uses two tax rates, "Gazeta Prawna", no. 248, 2007, p. 20. 
changes proposed by PO do not go as far as those which were introduced in Ireland. This party declared that it wanted to simplify the tax system maximally by overruling exemptions granting unjustified privileges to some tax groups and introducing one $15 \%$ tax rate (the linear tax), maintaining the tax-free amount from taxation for a taxpayer and each child (pro-family tax relief). Therefore, as a result of the introduction of these solutions the tax-free amount would be retained, but the tax thresholds would be liquidated. ${ }^{15}$

One may easily notice that propositions of PO are far from the solutions accepted in Ireland. PO does not consider the introduction of numerous tax relieves as in Ireland. Moreover, PO does not propose leaving two tax rates and tax thresholds related to them. In fact, the only shared solution is leaving the tax-free amount. However, it is difficult to estimate that this amount should be calculated as the amount corresponding to the Irish amount, i.e. 17.600 euro. In practice it means that even after potential implementation of PO's program, tax burdens of the employees in our country will be much higher than those of people working in Ireland.

One may notice as well that PO after the end of the election campaign in 2007 commenced to modify its previous propositions. Due to the opposition of other parliamentary parties the introduction of the linear tax was postponed. ${ }^{16}$

Polskie Stronnictwo Ludowe (PSL - Polish Peasant Party) ${ }^{17}$, PO's coalition partner in an election campaign, did not accept the proposition of liquidation of the tax thresholds. PSL assumed that except for the taxes which charge the poorest citizens, the reduction of the height of the direct taxes is impossible in the future. This party proposed a gradual increase of the amount free from the income tax from natural persons up to the level of social minimum along with further maintenance of three rates of the tax scale. PSL allowed the possibility of introducing the zero tax rate for taxpayers whose income did not exceed 900 PLN per month (10,8 thousand PLN per year), maintenance of degressive tax-free amount for the taxpayers of the Ist tax group and deprivation of the taxpayers of the IInd and IIIrd tax group of this amount. ${ }^{18}$

Before the election PSL did not support partial or full liquidation of tax thresholds at all. It supported the increase of the tax-free amount but only for the least paid employees, and called for the dependence of its height on the height of the social minimum.

\footnotetext{
15 To have a better life. PO' s program, PO's website www.platforma.org of 28 May 2008.

16 Tusk: The linear tax in 2011, the website of TVN24 www.tvn24.pl/12692,1547823,wiadomosc.html of 26 May 2008.

17 Hereinafter referred to as PSL

18 Social and Economic Program of PSL, the website of PSL www.psl.pl of 28 May 2008.
} 
The position of PSL politicians has been recently modified. Press releases show that now they do not exclude supporting propositions of PO provided that the taxfree amount and the pro-family relief for children are maintained. ${ }^{19}$

Other important parliamentary parties like "Prawo i Sprawiedliwość" (Peace and Justice) and "Lewica i Demokraci" (The Left and the Democrats) are not the supporters of the liquidation of tax thresholds and the introduction of one tax rate for all employees. They also do not agree to the possibility of liquidation of the taxfree amount.

"Prawo i Sprawiedliwość" was the initiator of the introduction of two tax rates: $18 \%$ and $32 \%$ in npita. This party does not consider changing solutions introduced previous year and finds them sufficient. ${ }^{20}$

"Lewica i Demokraci" is also the supporter of maintaining PIT rates at the current level. Additionally, it calls for the introduction of tax relief for social purposes, in particular for the development of culture, education and fighting social pathologies. ${ }^{21}$

There is no political as well as social (apparently) support for propositions of total liquidation of tax thresholds and the introduction of a homogenous tax rate for employees. There is also a lack of acceptance for the withdrawal from determining the tax-free amount. Such a solution is not proposed by any important political party. Even PO, at present the strongest party in the country and a great supporter of the introduction of the linear tax, supports the idea of maintaining the tax-free amount.

Due to the above, it is hardly possible to realize in practice the demands of introducing one universal linear income tax without tax thresholds, the tax-free amount and tax relieves. Such propositions should be considered as extreme. Thus, one may expect maintaining current solutions.

\section{Propositions of solutions}

To sum up, it is neither probable nor justified to resign from the progressive scale. The introduction of two tax thresholds and maintaining the tax-free amount from 2009 is reasonable. This solution is accepted by most political parties and has social support.

\footnotetext{
19 Pawlak: The linear tax but under one condition, the website of TVN24 www.tvn24.pl/12692,1548774, wiadomosc. html of 26 May 2008.

20 Efficient and friendly state taking care of its citizens, the website of Prawo i Sprawiedliwość www.pis.org.pl of 26 May 2008.

21 One hundred concrete terms. The program of Lewica i Demokraci, the website of Lewica i Demokraci www.sld. waw.pl of 28 May 2008.
} 
At first glance, a system similar to the Irish solutions, which due to its promarket character have also a lot of supporters in Poland, will be created. There will be two tax rates in Poland (like in Ireland) from 2009. In both countries the tax-free amount is also determined and tax relieves appear.

However, low calculation of the tax thresholds and the tax-free amount is not satisfying in our solutions. In this range our solutions are far from the Irish ones. $32 \%$ tax rate introduced from 2009 should be related only to the income of people who exceed the average remuneration several times. However, $32 \%$ tax rate from 2009 will concern the income of the amount higher than 85.528 PLN, i.e. about 7.100 PLN per month. This is the amount which does not exceed the amount of three average remunerations. ${ }^{22}$ In my opinion, it is too low. That is why this solution is not going to favor the creation of the middle class in Poland, which is a sign of rich societies.

The tax-free amount calculated in accordance with the provisions of npita (in 2009 it is 3.089 PLN per year) is also definitely too low. One may not state that it was established rationally since it does not include such rates as minimum remuneration or the social minimum (in December 2007 it was about 820 PLN per month). In my opinion, the taxation of the income lower than the social minimum is not only morally but also economically questionable. People who do not have the social minimum are very often entitled to social benefits financed by the state mostly from taxes. Thus, first the state "takes" the money in the form of tax in order to "return" it in the form of social support.

It would be better to establish the tax-free amount as a product of 12 months and the social minimum or minimum remuneration. All taxpayers should be entitled to the amount calculated in such a way. Further modification in the direction of more rational taxation of families would be possible, i.e. spouses would be entitled to additional tax-free amounts depending on a number of children. To sum up, one may state that similar solutions successfully function in Ireland. 


\section{Streszczenie}

Dyskusja na temat reformy istniejącego w Polsce systemu podatkowego toczy się od wielu lat. Systematycznie pojawiają się żądania radykalnego uproszczenia opodatkowania dochodów osób fizycznych poprzez likwidację ulg podatkowych i wprowadzenie jednej stawki. Celem propozycji zmian jest nie tylko uproszczenie systemu podatkowego, ale również obniżenie obciążeń podatkowych obywateli. Mogą być one osiagnięte także poprzez modyfikację progów podatkowych i podniesienie kwoty wolnej od podatku.

W artykule zostały przedstawione różne propozycje modyfikacji progów podatkowych i kwoty wolnej od opodatkowania w kontekście reformy dochodów osób fizycznych. 